Effects of brain-based learning strategies on secondary school students' motivation to learn in Federal Capital Territory, Abuja, Nigeria

Apeh, Hosea Abalaka

University of Abuja, Nigeria (hosea.apeh@uniabuja.edu.ng)

Iyiegbuniwe, O. A.

University of Abuja, Nigeria (omolara2004@gmail.com)

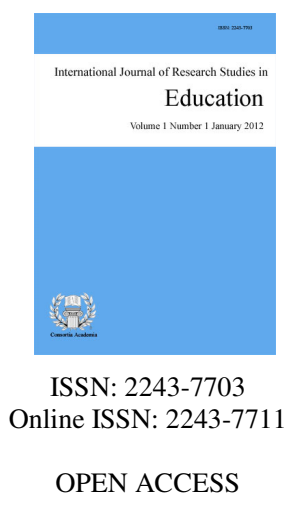

Received: 30 October 2020

Revised: 16 December 2020 DOI: $10.5861 /$ ijrse.2021.5057

Accepted: 23 January 2021

Available Online: 25 January 2021 DOI: $10.5861 / 1 \mathrm{jrse.2021.5057}$

\title{
Abstract
}

The study was carried out to find out whether Brain-Based Learning Strategies has any effect on Senior Secondary School Students Motivation towards Learning in the Federal Capital Territory, Abuja. The pre-test post-test Quasi Experimental Research design was used with a sample size of 142 Students drawn from two Senior Secondary Schools. Two intact classes were used; each assigned to the Control and Experimental group. Data for the study was sourced using Students' Motivation Scale (SMS). Hypotheses were tested at a significant level of 0.05 using ANCOVA. Findings revealed significant difference in the Motivation towards Learning in favor of the Experimental Group. No significant difference was observed in Motivation towards Learning of students based on gender. It was recommended that teachers should adopt the Brain-based learning strategies in teaching Economics in Senior Secondary Schools in order to improve on motivation. Gender biases in implementation of Brain-Based learning strategy should be discouraged.

Keywords: brain-based learning; conventional teaching method; motivation 


\section{Effects of brain-based learning strategies on secondary school students' motivation to learn in Federal Capital Territory, Abuja, Nigeria}

\section{Introduction}

An issue of great concern to educators and stakeholders in education is developing and maintaining student commitment to learning (education activities) particularly in adolescence. Researchers and theorists have noted a decline in academic motivation in the early adolescent years that, for some individuals continue throughout high school or culminate in "dropping out" (Timo \& Hanfsting, 2015). Such adolescents may fail to reach their academic potential. In the last four decades, educators and neuro-scientists, in order to improve learning experiences have focused on applying latest findings on how the brain works and how learning occurs to modify classroom practices. For example, in the 1990s, developments in technology have made it possible for researchers to see inside the brain, and visualize how the structures in the brain communicate.

The knowledge about brain function and its effects on learning have the potential to revolutionize teaching and learning. This understanding of how the brain works and relating it to the educational field birthed the concept of brain-based learning. Brain-based learning is a student-centered instructional approach that, involve the use of instructional strategies, which is designed for compatibility with the brain's propensities for seeking, processing, and organizing information (Kelly, 2013). The handy acronym IGNITE (intervals, grouping, novelty, interconnectedness, technology and time, environment) describes how to activate brain-based learning (Kelly, 2013).

Caine and Caine cited in Jack and Kyado (2017) explained that, brain-based learning involves accepting the rules of how the brain processes and then organizing these rules in mind to achieve meaningful learning. Brain-based learning as an instructional approach is based on the notion that, if the brain is functioning properly and is able to carry out its normal processes, learning will occur naturally (D'Costa, 2010). The brain-based education is designed to suit how the brain receives, processes and analyses information at its best. Jensen (2008) expressed it as education with the brain in mind.

Ramona (2013) expressed brain-based learning as teaching methods, lesson designs, and school programs based on the latest scientific discovery about how the brain receives and processes information, including such factors as cognitive development: how students learn differently as they age, grow, and mature socially, emotionally, and cognitively. BBL provides insight into not just how to structure learning, but the classroom set up, student assessment and support for social emotional learning. These also include good nutrition and healthy habits that are essential as they influence the brain function. D'Costa (2010) stated that when students are allowed to work collaboratively and build strong relationship with classmates they learn better.

Sousa (2011) stated that a brain-based approach integrates the engagement of emotion, nutrition, enriched environments, music, movement, meaning making and the absence of threat for maximum learner participation and achievement. Jensen (2008) described brain-based learning as a set of principles and a base of knowledge and skills through which we can make better decisions about the learning process. The merit of the BBL is evident in its ability to foster social interaction through individual learners' participation, thereby encouraging critical thinking.

Caine and Caine (2001) stated some principles that guides the instructional approach and identified certain conditions that enhance learning thus: 1-The brain /mind is social. 2-Learning is physiological. 3-The search for meaning is innate. 4-The search for meaning occurs through "patterning". 5-Emotions are critical to patterning. 6-The brain/mind processes wholes and parts simultaneously. 7-Learning involves both focused attention, and peripheral perception. 8-Learning always involves conscious and unconscious procedures. 9-Learning is 
developmental. 10-The brain understands and remembers when facts and skills are embedded in natural spatial memory. 11-Learning is enhanced by challenge and inhibited by threat. 12-Every brain is uniquely organized.

The three instructional conditions for learning are:

Orchestrated Immersion - This involves ensuring that students concentrate on concepts being learnt; teachers should relate concepts to real life situations (Caine \& Caine, 2011).

Relaxed Alertness - This optimal state of mind emphasizes that the learners should feel secure so that they can take a risk (Caine \& Caine, 2001). Teachers need to organize the class to ensure all manner of fear eliminated from the classroom (Gozuysil \& Dikicl, 2014; Thomas \& Swamy, 2014).

Active Processing - This means allowing the learner to process information by internalizing and consolidating such information.

Wieman (2013) explained that, learning is inherently hard work; it requires pushing the brain to its limits, and thus can only happen with motivation. Student motivation is one of the important elements of learning as it is the reasons or goals that underlie their involvement in academic activities. Amrai, Motlagh, Zalani, and Parhon, (2011) stated that, motivation for academic achievement, or internal motivation, is a psycho-cognitive condition which is acquired once the individual perceive him/herself to have autonomy. As such, when students are led to form their own meaning of concepts by taking charge of their own learning, they could be motivated to learn.

According to Brown (2000) motivation is one of the influential factors in learning that drives learners to struggle to reach their goals in the learning process and can become a stimulus in the learning process. The learning process is such that should take care of the three main learning domains; affective, cognitive and psychomotor. It becomes imperative for the teacher to look for ways of teaching that are justified on these grounds (Mansbach, 2017).

Usher and Kober (2012) opined that, motivation appears to have different sources for different students. The main source of strong motivation to engage in day-to-day academic tasks is subject interest. Motivation for academic achievement is attributed to students' beliefs and behaviors which lead to learning and achievement. When students form their own meaning of concepts by taking charge of their own learning, they could be motivated to learn. Usher and Kober (2012) stated further that, motivation is a fundamental recipe for academic success. If students are not motivated, it is difficult, if not impossible, to improve their academic achievement no matter how good the teacher, curriculum or school is.

Educators can do many things to create a classroom environment that motivate students to learn and behave in ways that promote their long-term success (Ormrod, 2012). Since motivation energizes, directs, and sustains behavior: it gets students moving, points them in a particular direction, and keeps them going. Students' motivation often reflected in personal investment and in cognitive, emotional, and behavioral engagement in school activities (Ormrod, 2012).

The conventional lecture method of teaching could be said to exhibit some of the following weaknesses: it generates surface knowledge, entails rote memorization of facts, promotes one-way communication, and lacks interaction between students and teachers therefore making learners passive observers in the classroom and restricted. However, the challenges that educators face in the 21 st century are so diverse that using better and appropriate teaching methods is more crucial now than ever before.

Although, the lecture method is effective in delivering knowledge to a large number of students and covering a wide range of topics within a stipulated time. Most teachers using lecture method only lump information on students rather than facilitate a learning process that would help learners acquire, assimilate and exhibit good knowledge of the subject as the method involves students receiving information mainly through input given by teachers in the classrooms. This however hinders students' innate learning potentials and ignores 
Apeh, H. A., \& Iyiegbuniwe, O. A.

students' individual differences leading to negative attitudes towards learning and its attendant poor academic performance.

Advocates of brain-based learning insist that there is a difference between "brain-compatible" education, and "brain-antagonistic" instructional practices and methods which can actually prevent effective learning. It is argued that teaching without an awareness of how the brain learns is like designing a glove with no sense of what a hand looks like its shape and how it moves. It is apparent that if classrooms are to be places of learning, then the brain as the organ of learning must be understood.

Brain-based learning strategy differs from conventional teaching strategy. A typical feature of conventional lecture method according to Brighton (2007) is the "teacher-dominated interaction". Aziz-Ur-Rehman (2011), on the other hand describe the brain-based learning as a student-centered method which engages the brain in the learning process by considering the natural functioning of its various parts. Conventional teaching method however, promotes rote memorization of facts. Conventional methods such as lectures may not be the best way to convey information even if it is a popular teaching technique. According to Sousa (2006), students on average retain only five percent of information delivered through lecture twenty-four hours later. Lessons therefore, should be designed to promote critical divergent thinking and equip students with information relevant to the real world and the ability to use such information as provided via brain-based learning strategy.

Brain-based learning present classroom activities that ensure learners emotion is taken into consideration drawing from the three conditions of learning as illustrated in Figure 1.

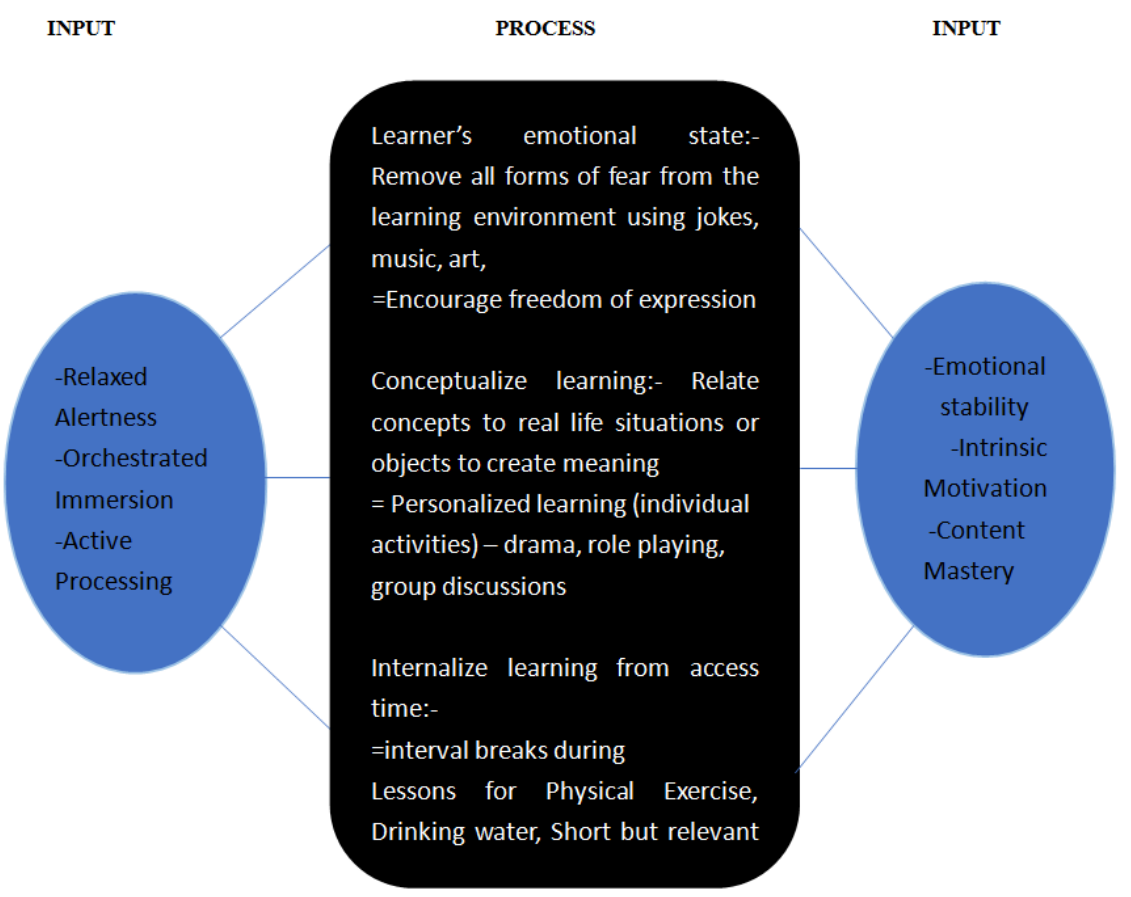

Figure 1. Brain-based learning input-process-output chart

The brain-based learning input-process-output (BBLIPO) chart illustrates the pathway to enhance brain function. Effective learning is achievable when the learners are not just present in the classroom but emotionally active and relevant to the learning process. The brain-based learning strategies, hinged on the three conditions for learning as proposed by Caine and Caine (2000), that is, the Relaxed Alertness, Orchestrated Immersion and Active Processing which requires the introduction of activities (input) that enhance brain function in order to achieve effective learning (output).

Brain-based learning theory relates with the multiple intelligences' theory in some features such as; the

22 Consortia Academia Publishing (A partner of Network of Professional Researchers and Educators) 
engagement of positive emotions, arousing intrinsic motivation, formation of multiple memory pathways, making real-life connections to help generate patterns and meaningful learning, and the consideration that each brain is unique and people have multiple intelligences at varying degrees. These two theories emphasize the importance of learners' individual difference as one of the major factors essential for achieving effective learning.

Several studies have asserted the effectiveness of brain-based instructional strategy on motivation to learn including:

Akyürek and Afacan (2013) in a study conducted in Turkey to examine the effect of brain-based learning approach on attitudes and motivation levels in 8th grade students' science classes. The study established the effect of brain-based learning approach on students' motivation. Jack and Kyado (2017) in a quasi-experimental research examined the 'effect of brain-based learning strategy on students' academic achievement, attitude, motivation and knowledge retention in Electrochemistry'. The result of the study affirmed the positive effect of BBL on students' motivation towards learning. Mekarina and Ningsih (2017) in their study, 'the effects of brain-based learning approach on motivation and students' achievement in mathematics learning affirms the effectiveness of brain-based learning in improving the student's motivation towards learning.

It is worth noting that learning becomes stronger and information retrieval becomes easier if senses are involved in the learning process, also, experiences linked to emotions are easier to remember. Therefore, learner-centered teaching environments represent an endeavor to assist learners to make connections between their previous knowledge and their current academic tasks (Bransford, Brown, \& Cocking, 2000). Focusing on the brain functions, thus, help paying attention to sensory perception, attention, memory and how emotions affected learning.

Other existing literature as evidenced by research conducted Lestari (2014); Nurhadyani (2010) concluded that the overall the motivation to study among students who learned math through brain-based learning was positive. The research by Kusmariyanti (2012) also reported increased study motivation among students with brain-based learning approach. Using brain-based learning approach, teachers can make studying to become more meaningful, optimizing brain development students, and enable student discussions. McCombs (2002); Cluck and Hess (2003) suggested that there are various ways to motivate children, depending on how they learn. Students' natural curiosity about the surrounding world can be sparked through more meaningful materials; among these is the Brain-based learning. Suwono and Dewi (2019) carried out analysis of various studies students' scientific motivation and communication while Tudor et al. (2019); Shimizu et al. (2019) focused on the mastery of knowledge due to BBL implementation.

In spite of several studies on Brain-based learning carried out by other researchers, existing research is still limited to a variety of specific research subjects. A review of available empirical studies on BBL and students' motivation reveals dearth of such studies in the Federal Capital Territory and majority of the existing studies have concentrated on the sciences and languages. This necessitated the conduct of this study.

\subsection{Statement of the problem}

The challenges that educators face in the 21st century is so diverse that using better and appropriate teaching methods is more crucial now than ever before. With current research findings on how the brain perceives, processes, stores and retrieves information, which is important to guide pedagogy; it is important that teachers adopt instructional strategies that would spur learners' interest in the learning process. The researchers believe that, learning of Economics could be more interesting and meaningful if teachers adopt appropriate instructional strategies in teaching concepts to students. This is because Economics is a subject that relates to everyday living and its principles are applicable to all economic units. Hence, the need to investigate if the brain-based learning strategies would have any effect on the senior secondary schools' students' motivation to learn. The specific objectives of this research were, to find out if: 
$>$ There is any difference in the students' motivation between experimental and control group at pre-test;

$>$ There is any difference in the students' motivation between experimental and control group at post-test; and

$>$ There is any difference in motivation between male and female students in the experimental group at post-test.

This study was guided by the following research questions:

$>$ What is the difference in students' motivation between the experimental group and the control group at pre-test?

$>$ What is the difference in students' motivation between the experimental group and the control group at post-test?

$>$ What is the difference in motivation between male and female students in the experimental group?

The following null hypotheses were tested at .05 level of significance:

$\mathrm{H}_{01^{-}}$There is no significant difference in pre-test and post-test mean motivation of students taught Economics using brain-based learning strategies and students taught Economics using conventional lecture methods.

$\mathrm{H}_{02}$-There is no significant difference in mean motivation of male and female students taught Economics using Brain-based learning strategies?

\section{Methodology}

The research design for the study is the pre-test post-test, control group design in a quasi-experimental setting. The quasi-experimental design is considered appropriate because the experimental and control groups were naturally assembled groups as intact classes so that the normal school setting is not disrupted. For this research, the researchers used two classes, one class for each of the two selected schools; each class representing a group. One class represented the experimental group (denoted as Group E) while the other class represented the control group (denoted as Group C).

The target population for this study comprised 16,894 students in Senior Secondary I in all the public Senior Secondary Schools in Abuja Municipal Area Council of the Federal Capital Territory that are offering Economics as a subject. The sample size for the study comprised 142 senior secondary one (S.S.1) students from two selected senior secondary schools. Two co-educational senior secondary schools were randomly selected using simple random sampling technique. The two selected schools were randomly assigned to the experimental group and control group using lucky dip. The experimental group has seventy (70) students while the control group had seventy-two (72) students.

The instrument used in this study is the Student Motivation Scale (SMS) is a questionnaire designed along a four-point Likert type scale with 12 items modified, and four options namely; Strongly Agree (SA), Agree (A), Disagree (D), Strongly Disagree (SD). Student Motivation Scale (SMS) items were adapted by researchers from other existing motivation scale namely, Achievement Motivation Scale (AMS) by Demirel and Turan (2010). Students Motivation Scale (SMS) was used to determine students' motivation to learn.

To determine validity of the Students' Attitude Scale (SMS), experts in the field of education were consulted. The rating by the experts after observation, corrections and final consideration served as logical validity of the instruments. For reliability of the instrument, the SMS was subjected to pilot test by the researchers with 31 students (18 male students and 13 female students) in a Government Secondary School within the study area. 
Reliability of SMS was determined using Cronbach's alpha reliability coefficient; the value of Cronbach's alpha reliability coefficient normally ranges from 0 and 1 . With the value of 0.76 , the items on the SAS scale were judged to have a good internal consistency.

\subsection{Experimental procedure}

The procedure began with a pre-test where a version of the instrument was administered to the participants to establish their initial status before the commencement of treatment. The treatment tool for the experiment is the lesson plan designed using the 12 principles of brain-based learning strategies and the three conditions of learning (relaxed alertness, orchestrated immersion and active processing) developed by Caine \& Caine (2001) and the lesson plan for the conventional lecture method. The lesson plan for the two groups was prepared by the researchers for consistency in lesson presentation for the groups. The researchers drafted a teacher's guideline for the study based on the principles of Brain-based learning strategies (BBLS).

\subsection{Teacher's guideline on teaching economics using brain-based learning strategies}

$>$ A balance diet chart was displayed in the classroom and teacher informs learners before the lessons about the importance of nutrition and hydration to their brain development and function.

$>\quad$ Teacher encouraged students to come with drinking water in their water bottles, which students took during the lessons to maintain body hydration and reduce stress.

$>$ Teacher, during the first lesson enlighten students on the importance of food intake to their physical development and the consumption of water for good brain health and function in accordance with Hans (2012) and Wilson (2013).

$>$ Diagrams used in learning some concepts and most group assignments were displayed in the classroom.

$>$ Students were encouraged to reflect on previous knowledge.

$>$ Teacher created a stimulating environment to take care of students' emotion using means such as: playing soft or classical music on few occasions, cheerful environment through brain energizers and sarcasm free jokes.

$>\quad$ Students are motivated using praise or positive adjectives chosen by each student as a prefix to their name for example Intelligent Henry, Smart Adamu, Charming Sochi e.t.c; this really boosted students' self-esteem.

$>$ Concepts were broken down to manageable parts to enable students internalize them easily and form meaning.

$>$ Class was broken into groups using various formats such as birth months, first alphabet of name, number of siblings, etc. This is to encourage peer interaction and learning. The groups engaged in group discussions, projects, role playing; thereafter students were allowed to evaluate themselves across groups without criticism.

$>$ Teacher encouraged students to freely express their fears, confusions and ideas as regards each module of topic taken.

$>\quad$ Teacher generated friendly environment by encouraging smiles and laughter, through teacher's friendly attitude towards students and physical exercise.

$>\quad$ Students were encouraged to form their own patterns as they learn; the teacher can do this by posing 
questions that will inspire curiosity in students or allowing time for reflection on new information. This promoted critical thinking and subsequently presentation of meaningful contents by merging new ideas into existing ones.

$>$ Students were also encouraged to perform individual task of their choice as it relates to learning concepts.

$>$ Innovations were appreciated and ambiguities acknowledged.

The experimental group was taught by the researchers led by a team member who is an Economics teacher while the control group was taught by the school Economics teacher with the researchers as observers based on the school management arrangement. The post-test version of Students' Motivation Scale (SMS) was administered to the two groups at the ten (10) weeks of study to assess the basic knowledge of Economics attained after treatment.

The administration of the Students' Motivation Scale lasted for a period of 30 minutes. The items on the SMS questionnaire were scored on a 1, 2, 3 and 4 range as follows: Strongly Agree $(\mathrm{SA})=4$ points, Agree $(\mathrm{A})=$ 3 points, Disagree $(D)=2$ points, Strongly Disagree $(S D)=1$ point. The negative questions were scored on the reverse as follows: Strongly Agree $(\mathrm{SA})=1$ points, Agree $(\mathrm{A})=2$ points, Disagree $(\mathrm{D})=3$ points, Strongly Disagree $(\mathrm{SD})=4$ point. A weighted score points of 2.5 was chosen as the benchmark, any score from 2.5 and above was recorded as agreement while score below 2.5 was rated as disagreement. The 2.5 benchmark represents the average of the four scales, which are $4+3+2+1=10 / 4=2.5$.

The data collected were analyzed using both descriptive and inferential tools of statistical analysis. Descriptive statistical tools mainly; mean, and standard deviations were used to answer the research questions. On the other hand, an inferential statistical tool such as independent sample t-test was used to analyze data. Statistical Package for Social Sciences (SPSS) computer software (version 23) was used to compute the data collected.

\section{Results}

Research Question One: What is the difference in students' motivation between the experimental group and the control group at pre-test?

\section{Table 1}

Pre-test scores of students' motivation for experimental and control group

\begin{tabular}{|c|c|c|c|c|c|c|c|}
\hline \multirow{2}{*}{ S/No. } & \multirow{2}{*}{ Statement } & \multicolumn{3}{|c|}{ Control } & \multicolumn{3}{|c|}{ Experimental } \\
\hline & & Mean & $S D$ & Decision & Mean & $S D$ & Decision \\
\hline 1 & I enjoy learning Economics & 2.74 & 1.05 & Agree & 2.79 & 1.02 & Agree \\
\hline 2 & $\begin{array}{l}\text { Learning Economics, to me is boring and waste of } \\
\text { time }\end{array}$ & 2.69 & 1.11 & Agree & 2.86 & 1.19 & Agree \\
\hline 3 & I offer Economics because it is compulsory & 2.58 & 1.00 & Agree & 2.53 & 1.02 & Agree \\
\hline 4 & Learning Economics is really fun and interesting. & 2.81 & 1.04 & Agree & 2.84 & 1.12 & Agree \\
\hline 5 & I can succeed in my Economics if I work hard & 2.89 & 1.18 & Agree & 2.81 & 1.12 & Agree \\
\hline 6 & I put in my best in my academics. & 2.69 & 1.15 & Agree & 2.99 & 1.15 & Agree \\
\hline 7 & Supportive teachers encourage me to learn. & 2.79 & 1.09 & Agree & 2.94 & 1.13 & Agree \\
\hline 8 & I do not care about school or learning. & 2.68 & 1.29 & Agree & 2.97 & 1.19 & Agree \\
\hline 9 & I do not take part in class discussion or group work. & 2.72 & 1.14 & Agree & 2.84 & 0.96 & Agree \\
\hline 10 & $\begin{array}{l}\text { The classroom environment makes me feel safe and } \\
\text { relaxed during Economics lessons. }\end{array}$ & 2.81 & 1.05 & Agree & 2.70 & 1.17 & Agree \\
\hline 11 & $\begin{array}{l}\text { I believe I can learn from my interaction with my } \\
\text { peers. }\end{array}$ & 2.85 & 1.07 & Agree & 2.83 & 1.15 & Agree \\
\hline \multirow[t]{2}{*}{12} & $\begin{array}{l}\text { I am comfort and confident expressing my views in } \\
\text { class. }\end{array}$ & 2.64 & 1.12 & Agree & 2.60 & 1.04 & Agree \\
\hline & Overall Mean & 2.74 & & Agree & 2.81 & & Agree \\
\hline
\end{tabular}

Table 1 indicates that, with an overall mean score of 2.81 and 2.74 , the learners in the experimental and 
control groups respectively exhibit a similar level of motivation towards Economics. Therefore, there is very minimal difference in level of motivation toward Economics between the two groups before the treatment with a mean difference of 0.07 in favor of the experimental group. This implies that the two groups of students were relatively identical in their motivation for learning before the commencement of treatment using the two instructional strategies.

Research Question Two: What is the difference in students' motivation between the experimental group and the control group at post-test?

\section{Table 2}

Post-test mean scores of students on motivation for the control and experimental group

\begin{tabular}{|c|c|c|c|c|c|c|c|}
\hline \multirow{2}{*}{ S/No. } & \multirow{2}{*}{ Statement } & \multicolumn{3}{|c|}{ Control } & \multicolumn{3}{|c|}{ Experimental } \\
\hline & & Mean & $S D$ & Decision & Mean & $S D$ & Decision \\
\hline 1 & I enjoy learning Economics & 3.46 & 0.59 & Agree & 3.49 & 0.58 & Agree \\
\hline 2 & $\begin{array}{l}\text { Learning Economics, to me is boring and waste of } \\
\text { time }\end{array}$ & 3.35 & 0.77 & Agree & 3.51 & 0.75 & Agree \\
\hline 3 & I offer Economics because it is compulsory & 2.68 & 0.99 & Agree & 3.34 & 0.74 & Agree \\
\hline 4 & Learning Economics is really fun and interesting. & 3.40 & 0.66 & Agree & 3.50 & 0.58 & Agree \\
\hline 5 & I can succeed in my Economics if I work hard & 3.18 & 1.09 & Agree & 3.54 & 0.67 & Agree \\
\hline 6 & I put in my best in my academics. & 3.38 & 0.90 & Agree & 3.59 & 0.75 & Agree \\
\hline 7 & Supportive teachers encourage me to learn. & 3.10 & 0.98 & Agree & 3.60 & 0.57 & Agree \\
\hline 8 & I do not care about school or learning. & 3.35 & 0.83 & Agree & 3.74 & 0.60 & Agree \\
\hline 9 & I do not take part in class discussion or group work. & 2.97 & 1.06 & Agree & 3.26 & 0.89 & Agree \\
\hline 10 & $\begin{array}{l}\text { The classroom environment makes me feel safe and } \\
\text { relaxed during Economics lessons. }\end{array}$ & 2.68 & 1.07 & Agree & 3.43 & 0.67 & Agree \\
\hline 11 & $\begin{array}{l}\text { I believe I can learn from my interaction with my } \\
\text { peers. }\end{array}$ & 2.93 & 1.07 & Agree & 3.46 & 0.60 & Agree \\
\hline \multirow[t]{2}{*}{12} & $\begin{array}{l}\text { I am comfort and confident expressing my views in } \\
\text { class. }\end{array}$ & 3.24 & 0.81 & Agree & 3.63 & 0.51 & Agree \\
\hline & Overall Mean & 3.14 & & Agree & 3.51 & & Agree \\
\hline
\end{tabular}

Table 2 indicates that, with an overall mean score of 3.51 learners in the experimental group exhibited a higher level of motivation in Economics compared to their counterparts in the control group with a mean score of 3.14. Therefore, there is a difference in attitude towards learning of Economics between the two groups in favor of the experimental group. The results show that the students in the experimental group show stronger assertion to the items on the motivational scale at post-test while the students in the control group showed less motivation for learning. Therefore, there is difference in level of motivation towards Economics between the two groups ascribable to use of brain-based learning strategy.

Research Question Three: What is the difference in Motivation between male and female students in the experimental group?

Table 3

Mean and standard deviation on motivation of male and female students in the experimental group

\begin{tabular}{lcccc}
\hline \multicolumn{1}{c}{ Gender } & $N$ & Mean & $S D$ & SE Mean \\
\hline Male & 37 & 3.49 & 0.17 & 0.03 \\
Female & 33 & 3.53 & 0.18 & 0.03 \\
\hline
\end{tabular}

The result presented in Table 3 reveals a difference in the motivations towards Economics for the male and female students in the experimental group. There was a higher mean score on motivation towards Economics for male students with $($ mean $=3.49, \mathrm{SD}=0.17)$, compared to that of female students with $($ mean $=3.53, \mathrm{SD}=0.18)$. There is a mean difference of 0.04 in favor of the male students. This result implies that, the mean score of male students in the experimental group on motivation for learning Economics is slightly higher than that of the female students in the group after the group was taught Economics using Brain-based learning strategies. 
Apeh, H. A., \& Iyiegbuniwe, O. A.

$\mathbf{H}_{\mathbf{0 1}}$ : There is no significant difference in level of motivation between students in the experimental group and students in the control group at pre-test.

\section{Table 4}

T-test result of difference in students' motivation between the control and experimental groups at pre-test

\begin{tabular}{lccccccc}
\hline \multicolumn{1}{c}{ Group } & $N$ & Mean & $S D$ & $\mathrm{df}$ & $t$-value & Sig. & Decision \\
\hline Control & 72 & 2.74 & 0.55 & 140 & -.73 & 0.470 & Accepted \\
Experimental & 70 & 2.81 & 0.55 & & & & \\
\hline
\end{tabular}

Table 4 shows an independent-sample t-test conducted to compare students' motivation between the control and experimental groups before the commencement of treatment. There was not a significant difference in the scores for motivation of students in the control group $(\mathrm{M}=2.74, \mathrm{SD}=0.55)$ and motivation of students in the experimental group $(\mathrm{M}=2.81, \mathrm{SD}=0.55)$ conditions; $\mathrm{t}(140)=-.073, p=0.470$. This implies that there is no significant difference in learning motivation of students in the experimental and control groups before the two instructional strategies were employed as treatment.

$\mathbf{H}_{02}$ : There is no significant difference in level of motivation between students in the experimental group and students in the control group at post-test.

\section{Table 5}

T-test result of difference in students' motivation between the control and experimental groups at post-test

\begin{tabular}{lccccccc}
\hline \multicolumn{1}{c}{ Group } & $N$ & Mean & $S D$ & df & $t$-value & Sig. & Decision \\
\hline Control & 72 & 3.14 & 0.38 & 140 & -7.35 & .000 & Rejected \\
Experimental & 70 & 3.51 & 0.18 & & & & \\
\hline
\end{tabular}

Table 5 shows independent-samples t-test conducted to compare students' motivation between the control and experimental groups after the treatment (posttest). There was significant difference in the scores for motivation of students in the control group $(\mathrm{M}=3.14, \mathrm{SD}=0.38)$ and motivation of students in the experimental group $(\mathrm{M}=3.51$, $\mathrm{SD}=0.18)$ conditions; $\mathrm{t}(140)=-7.35, p=0.000$. This implies that students who were taught Economics using brain-based learning strategies showed greater improvement in their motivation for learning of the subject while those taught using the conventional lecture method showed less improvement. This result demonstrates that brain-based learning strategy is more effective in improving students' motivation for learning than the conventional teaching strategy.

$\mathbf{H}_{\mathbf{0 3}}$ : There is no significant difference in mean scores on motivation between male and female students in the experimental group.

\section{Table 6}

T-test result of difference in mean scores on motivation between male and female in the experimental group

\begin{tabular}{llcccccc}
\hline \multicolumn{1}{c}{ Gender } & $N$ & Mean & $S D$ & df & $t$-value & Sig. & Decision \\
\hline Male & 37 & 3.49 & 0.17 & 68 & -.84 & .406 & Accepted \\
Female & 33 & 3.53 & 0.18 & & & & \\
\hline
\end{tabular}

Table 6 shows an independent-samples t-test conducted to compare male and female students' motivation after the treatment (posttest). There was not a significant difference in the scores for motivation of male students $(\mathrm{M}=3.49, \mathrm{SD}=0.17)$ and female students $(\mathrm{M}=3.53, \mathrm{SD}=0.18)$ conditions; $\mathrm{t}(68)=-.84, p=.406$. This implies that 
Effects of brain-based learning strategies on secondary school students' motivation to learn in Nigeria

improvements in students' motivation for learning of Economics due to intervention with brain-based learning strategy is not dependent on gender and can be adopted to improve learners' motivation irrespective of gender.

\section{Discussion of findings}

The first finding is this study relates to the motivation of students towards learning Economics before the commencement of treatment. The students included those in the experimental and control groups. Students in both groups were in agreement on most items on the questionnaire on motivation. However, the experimental group recorded a slightly higher mean score on motivation for learning compared to that of the control group with mean of 2.81 and 2.74 respectively. This difference however was not statistically significant when tested at 0.05 significant levels. With this result, the researchers established that the two groups did not exhibit significant differences in their motivation for learning of Economics before the treatment began. This finding implies that prior to treatment, the control and experiment were similar in motivation for the subject; any observed difference during the post treatment stage can thus be attributed to treatment effects. This affirms studies by Jack and Kyado (2017); Akyurek and Afacan (2013) who also observed that, the pre-test mean scores on motivation for learning of the experimental and control group was not statistically significant.

Secondly, the study established that difference in post-test mean score on motivation for learning by the two groups was statistically significant. The students in the experimental group recorded more improvement in mean score on motivation for learning than the control group. This result revealed that the Brain-based learning strategies implemented in the experimental group has a positive effect on the students' motivation for learning Economics. These finding are in tandem with the findings of Mekarina and Ningsih (2017); Jack and Kyado (2017); Akyurek and Afacan (2013); Saleh (2011); Inci (2010); Yildirim (2010). It was also observed by Akyurek and Afacan (2013) that participants in the experimental group taught using the Brain-based learning principles were more motivated than the participants in the control group who were taught using the Lecture-based teaching method.

The result also corroborates findings of other researchers such as Mekarina and Ningsih (2017) who in their study reported that, students agreed that they are motivated with the implementation of Brain-based learning approach. This was established by Duman (2006) in a study which revealed that, Brain-based learning approach do not just increase the students learning outcome, but also build students motivation and teachers get better. Brain-based learning was proven to also improve the result of students work and increase students' interest in learning. It can be concluded therefore that, implementation of Brain-based learning strategies improves students' motivation.

Saleh (2011) similarly reported that Brain-based learning approach is an effective instrument for increasing students' motivation. The effectiveness of increasing students' motivation by implementing the Brain-based principles in the classroom was further established by Jack and Kyado (2017) who stated that, Brain-based learning strategies helped in the development of high motivations and reduced difficulty level.

The finding however, contradicts the views of Weiner (2010) who observed that, some brain-based motivation is not positive because it depends on each learner's perspective. Weiner stated that, one student may fail a test and be motivated to study harder while another may fail the same test and be discouraged. Torio and Cabrillas-Torio (2016) claimed that, the Brain-based motivation is determined by brain dominance (left, middle and right). Torio and Cabrillas-Torio observed that Brain-based motivation bear more relevance to right-brain dominant students since this group of students are more emotional and intuitive and are more intrinsically motivated.

On gender interferences among students subject to treatment using brain-based learning strategy, this study revealed a greater improvement in motivation for learning of Economics by male students compared to their female counterparts. However, a t-test analysis on the difference in motivation on the basis of gender showed no significant difference between male and female students in the experimental group. This finding is in agreement 
Apeh, H. A., \& Iyiegbuniwe, O. A.

with the reports of Yildirin (2010); Akyurek and Afacan (2013). All these studies revealed that the effect of brain-based learning on students' motivation is not influenced by gender. As such the researchers concluded that, the Brain-based learning strategies reflect a positive effect on student motivation and should be implemented irrespective of gender.

\section{Conclusion and recommendations}

This study examined the effect of Brain-based learning strategies on senior secondary school students' motivation to learn. Result from the study asserts that Brain-based learning strategies led to higher motivation to learn Economics. The researchers also concluded that brain-based learning is effective and applicable even across gender. It was deduced that when teachers implement strategies that encourage students to think for themselves, generate ideas and information from past and present experiences through interaction with peers (team work), in a safe and relaxed environment, students enjoy good motivation to learn. The incorporation of the Brain-based learning strategies encouraged students to be actively involved in their own learning, which motivated the student to learn. The implementation of the strategies provided the opportunity for teachers to observe the students and carryout objective assessment of students. Brain-based learning strategies if implemented, promises to improve learning generally, motivate learners to learn in view of favorable learning conditions and reduce pressure on teachers who are consistently under pressure to ensure that learners do well. The free movement across groups to brainstorm and exchange ideas encourage students socialize amongst themselves and provides opportunities to enhance emotional awareness and improve learners' self-esteem. Active processing for internalizing learnt concepts could be achieved through questioning, jokes and short stories to create time out (break).

The findings of the study help students to attain their desire to internalize the knowledge acquired and be able to apply such knowledge in the future when the need arises. The study also serves as a guide to curriculum planners in identifying and understanding curriculum content that cater for the need of all learners. The findings of this study provide teachers with ideas that may help them to understand and accept their place as facilitators of learning rather than providers of information. A deep understanding of how the brain works (receives process and analyzes information) and the diverse needs of students encourage teachers to be more dynamic and resourceful in designing their lessons to suit learners' diverse needs; as they explore and adopt appropriate teaching methods to teach students. The findings of this study provide a clue on what policies and programs to put in place in order for the nation to achieve her aims and objectives in the education sector.

This study on the subject Economics differs from existing works whose focus appears to be in the sciences and languages. Herein is the contribution to existing knowledge. It was therefore recommended that:

$>$ Teachers should ensure to provide a relaxed environment with low threat and high challenging environment in order to ensure that learning environment is stress-free and making it a good source of motivation.

$>$ Practicing school teachers in the Federal Capital Territory (FCT), should adopt instructional strategies that would encourage self-learning and incorporates the individual differences amongst learners in the learning process.

$>$ Economics teacher in the Federal Capital Territory should apply the Brain-based learning strategies because of its relevance in improving learners' motivation.

$>$ Teachers should encourage good nutrition, physical exercise, movement, sarcasm free jokes, art (music), drama, drinking of water before and during lessons. Such activities can be rewarding and thus motivational.

$>$ Brain-compatible strategies can be implemented in single sex and co-educational schools since there

30 Consortia Academia Publishing (A partner of Network of Professional Researchers and Educators) 
Effects of brain-based learning strategies on secondary school students' motivation to learn in Nigeria

are mixed reports of its effect on gender.

\section{References}

Akyurek, E., \& Afacan, O. (2013). Effects of brain-based learning approach on students' motivation and attitudes levels in science class. Mevlana International Journal of Education, 3(1), 104-119. https://doi.org/10.13054/mije.13.08.3.1

Amrai, P., Motlagh, S. E., Zalani, H. A., \& Parhon, H. (2011). The relationship between academic motivation and academic achievement students. Procedia Social and Behavioral Sciences, 15(2), 399-402. https://doi.org/10.1016/j.sbspro.2011.03.111

Aziz-Ur-Rehman. (2011). Effectiveness of brain-based learning method and conventional method in the teaching of Mathematics at secondary level in Pakistan: An experimental study [Doctoral dissertation, International Islamic University, Islamabad]. http://prr.hec.gov.pk/Thesis/1546S.pdf

Bransford, J. D., Brown, A. L., \& Cocking, R. R. (2000). How people learn: Brain, mind, experience, and school. Washington, DC: National Academy of Sciences.

Brighton, K. L. (2007). Coming of age: The education and development of young adolescents. Westerville, $\mathrm{OH}$ : National Middle School Association.

Brown, H. D. (2000). Principles of language learning and teaching. White plains. N.Y: Longman.

Caine, G., \& Caine, R. (2000). The learning community as a foundation for developing teacher leaders. NASSP Bulletin, 84(616). https://doi.org/10.1177/019263650008461603

Caine, G., \& Caine, R. (2001). The brain, education, and the competitive edge. Lanham, MD: Scarecrow Press

Caine, G., \& Caine, R. (2011). How new research on learning is re-writing how schools work and teachers teach. Learning Landscapes, 5(1), 19-25. https://doi.org/10.36510/learnland.v5i1.527

Cluck, M., \& Hess, D. (2003). Improving student motivation through the use of the multiple intelligences [Master of Arts Action Research Project, Saint Xavier University]. Skylight Professional Development Field-Based Master's Program.

D’Costa, C. (2010). Brain based learning. https://www.Shutterstock.com/Rawpixel.com

Demirel, M. A., \& Turan, B. (2010). The effects of problem-based learning on achievement, attitude, metacognitive awareness and motivation. Hacettepe University Journal of Education, 38, 55-56.

Duman, B. (2006). The effect of brain-based instruction to improve on students' academic achievement in social studies instruction. Paper presented at the meeting of the ICEE 2006 9th International Conference on Engineering Education, San Diego, CA.

Gozuysil, E., \& Dikici, A. (2014). The effect of brain-based learning on academic achievement: A meta-analytical study. Educational Sciences: Theory \& Practice, 14(2), 642-648. https://doi.org/10.12738/estp.2014.2.2103

Hans, V. (2012). Study of the day: Mild dehydration alters mood, makes thinking hard. The Atlantic. https://www.theatlantic.com/health/archive/2012/02/...dehydration.../253320/

Inci, N. (2010). The effect of brain-based learning on academic achievement, attitude and retrieval of information in science and technology classes [Unpublished Master's Thesis]. Elazig: Firat University.

Jack, G. U., \& Kyado, J. J. (2017). Effectiveness of brain-based learning strategy on students' academic achievement, attitude, motivation and knowledge retention in electrochemistry. Journal of Education, Society and Behavioral Science, 21(3). https://doi.org/10.9734/JESBS/2017/34266

Jensen, E. (2008). A fresh look at brain-based education. Phi Delta Kappan, 89(6), 408- 417. https://doi.org/10.1177/003172170808900605

Kelly, R. (2013). Brain-based online learning design. http://www.facultyfocus.com/articles/online-education/brain-based-online-learning-design/

Kusmariyatni, N. (2012). Model brain-based learning. Jurnal Pendidikan dan Pengajaran, 46(2), 165-173.

Lestari, K. E. (2014). Implementation of brain-based learning to improve connection skills, critical thinking ability and learning motivation for Junior High School Students. Unsika Education Journal, 2(1), $36-46$. 
Apeh, H. A., \& Iyiegbuniwe, O. A.

Mansbach, J. (2017). How to ignite students'learning using brain-based principles. http://dl.sps.northwest.edu/author/jmansbach/

McCombs, B. L. (2002). Understanding the keys to motivation to learn. http://www.ncrel.org/products/votewarthy/barbaram.asp.

Mekarina, M., \& Ningsih, Y.P. (2017). The effects of brain-based learning approach on motivation and students' achievement in mathematics learning. Journal of Physics: Conf. Series 895012057 https://doi.org/10.1088/1742-6596/895/1/012057

Nurhadyani, D. (2010). Application of brain-based learning in mathematics learning to improve student motivation and mathematical connection ability (experimental study of Class IX students of a State Junior High School in Bandung Regency) [Unpublished thesis]. FPMIPA UPI.

Ormrod, J. (2012). Human learning (6th ed.). Pearson.

Ramona, P. (2013). Education, the brain, and common core state standards. iStockphoto. https://www.Shutterstock.com/Rawpixel.com

Saleh, S. (2011). The effectiveness of the brain-based teaching approach in generating students' learning motivation towards the subject of Physics: A qualitative approach. US-China Education Review, 1, 63-72.

Sousa, D. A. (2006). How the brain learns ( $3^{\text {rd }}$ ed.). Corwin Press.

Sousa, D. A. (2011). Mind, brain, and education: the impact of educational neuroscience on the science of teaching. Learning Landscapes, 5(1), 37-43. https://doi.org/10.36510/learnland.v5i1.529

Suwono, H., \& Dewi, E. K. (2019). Problem-based learning blended with online interaction to improve motivation, scientific communication and higher order thinking skills of high school students. In AIP Conference Proceedings. https://doi.org/10.1063/1.5094001

Thomas, B. M., \& Swamy, S. S. (2014). Brain-based teaching approach: A new paradigm of teaching. International Journal of Education and Psychological Research, 3(2), 62-65.

Timo, G., \& Hanfsting, B. (2015). The decline of academic motivation during adolescence: An accelerated longitudinal cohort analysis on the effect of psychological need satisfaction. Educational Psychology 36(9), 1698-1712. https://doi.org/10.1080/01443410.2015.1113236

Torio, V. A. G., \& Cabrillas-Torio, M. Z. (2016). Whole brain teaching in the Philippines: Teaching strategy for addressing motivation and academic performance. International Journal of Research Studies in Education, 5(3), 59-70. https://doi.org/10.5861/ijrse.2015.1289

Tudor, C. L., Kyaw, B. M., Dunleavy, G., Smart, N. A., Semwal, M., Rotgans, J. I., Low-Beer, N., \& Campbell, J. (2019). Digital problem-based learning in health professions: Systematic review and meta-analysis by the digital health education collaboration. Journal of Med Internet Res, 21(2), e12945 https://doi.org/10.2196/12945

Usher, A., \& Kober, N. (2012). Student motivation: An overlooked piece of school reforms. Center on Education Policy. https://files.eric.ed.gov/fulltext/ED532666.pdf

Weiner, B. (2010). The development of an attribution-based theory of motivation: A history of ideas. Education Psychology, 45, 28-36. https://doi.org/10.1080/00461520903433596

Wieman, C. (2013). Motivating learning. https://www.cwsei.ubc.ca

Wilson, L. O. (2013). The Brain-based education: An overview - The second principle. https://www.thesecondprinciple.com/optimal-learning/brainbased-education-an-overview

Yildirim, O. (2010). The effect of Brain-based learning on achievement, attitude and motivation [Unpublished master thesis]. Zonguldak Karaelmas University, Zonguldak. 